\title{
Natural occurrence of a Begomovirus on Dimorphotheca sinuata in India
}

\author{
S. K. Raji, B, M. S. Khan ${ }^{\mathrm{A}}$, S. K. Snehi ${ }^{\mathrm{A}}$, S. Kumar ${ }^{\mathrm{A}}$ and A. A. Khan ${ }^{\mathrm{A}}$ \\ APlant Molecular Virology Lab, National Botanical Research Institute (NBRI), Rana Pratap Marg, \\ Lucknow 226001, India. \\ ${ }^{\mathrm{B}}$ Corresponding author. Email: skraj2@rediffmail.com
}

\begin{abstract}
Association of a whitefly-transmitted Begomovirus with yellow net disease of Dimorphotheca sinuata is reported for the first time from India based on PCR amplification and sequence analysis of the coat protein gene region.
\end{abstract}

Dimorphotheca sinuata (family Asteraceae), also known as 'African Daisy', is a common ornamental species used mainly as a bedding plant in gardens. During winter of 2005-06, $\sim 25 \%$ of $D$. sinuata plants growing in the NBRI garden at Lucknow had yellow vein net symptoms on leaves (Fig. 1). The causal pathogen was suspected to be a begomovirus due to the large population of whitefly (Bemisia tabaci; the vector of begomoviruses) observed in the growing beds and the similarity of the yellow net symptoms to those caused by begomoviruses. The presence of a begomovirus was confirmed by PCR using begomovirus coat protein gene-specific primers (Singh 2005) and total DNA extracts from leaf tissues of

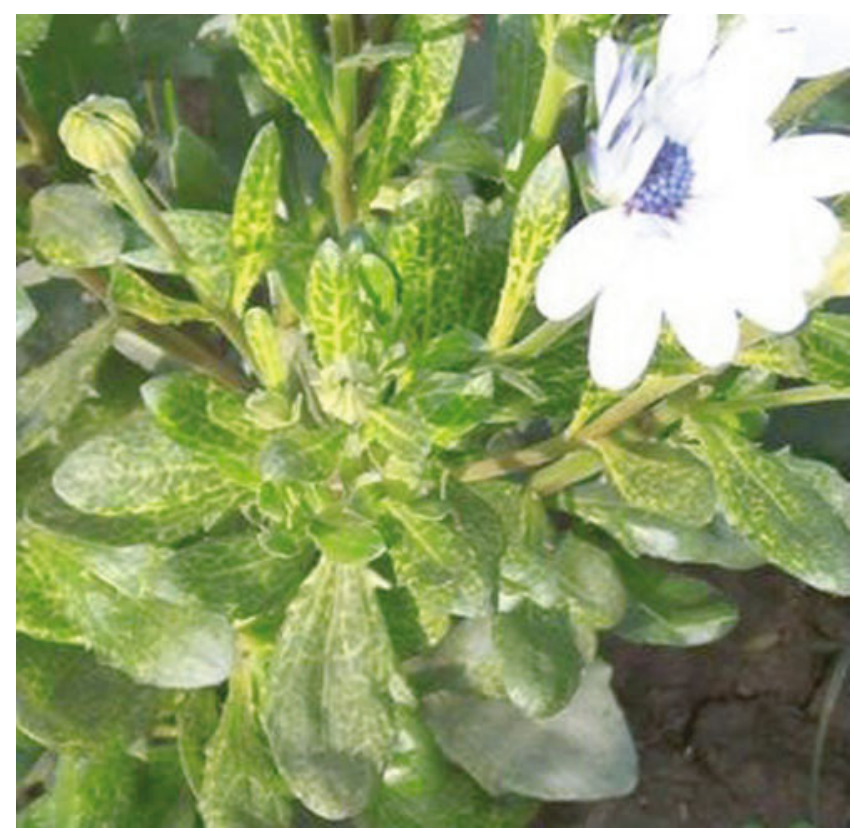

Fig. 1. Naturally infected Dimorphotheca sinuata plant showing yellow vein net symptoms. three naturally infected Dimorphotheca plants showing severe, moderate and mild yellow net symptoms. An amplicon of the expected size $(\sim 800 \mathrm{bp})$ was obtained from DNA of all the infected plants but not from a healthy plant. The PCR product was cloned, sequenced and the $771 \mathrm{bp}$ sequence data submitted to GenBank (Accession number DQ515969). Blast search analysis of nucleotide sequence of the virus shared 98-97\% identity with Tomato leaf curl virus (ToLCV) isolates from India (DQ343286, AY887174, AY690431) and 96\% identity with Tobacco curly shoot virus (TobCSV) isolates (AF240675, AJ420318, AJ971266, AJ457986). Phylogenetic analysis of the virus isolate also revealed a close relationship with ToLCV and TobCSV begomoviruses (Fig. 2).

$D$. sinuata has been reported to be the natural host of six viruses: Alfalfa mosaic virus, Cucumber mosaic virus, Lettuce mosaic virus, Tomato spotted wilt virus, a carlavirus (Lisa 1995; Manoussopoulos et al. 1999) and a nepovirus (Raj et al. 1994). As these viruses are mechanically transmissible, mechanical inoculations were made using sap of naturally infected Dimorphotheca onto three plants each of: Nicotiana tabacum cv. White Burley, Lycopersicon esculentum cv. Pusa Ruby, Capsicum annuum cv. Pusa Jwala and Datura metel. Neither local nor systemic symptoms developed on the test plants up to 25 days after inoculation. The virus was successfully transmitted to the above host plants by whiteflies (B. tabaci) using 10 whiteflies with an acquisition and inoculation access period of $12 \mathrm{~h}$ each on donor and recipient hosts, which developed leaf curl symptoms after 15-20 days and were found positive when checked by PCR.

Based on negative sap transmission, positive whitefly transmission, amplification of an expected size ( $~ 800 \mathrm{bp})$ amplicon by PCR using begomovirus-specific primers, high sequence identity (98-96\%) and a close phylogenetic relationship with ToLCV and TobCSV begomovirus, the virus causing yellow vein net disease in D. sinuata was identified as a begomovirus. To our knowledge, this is the first report of the association of a begomovirus with yellow net disease of D. sinuata from India. 


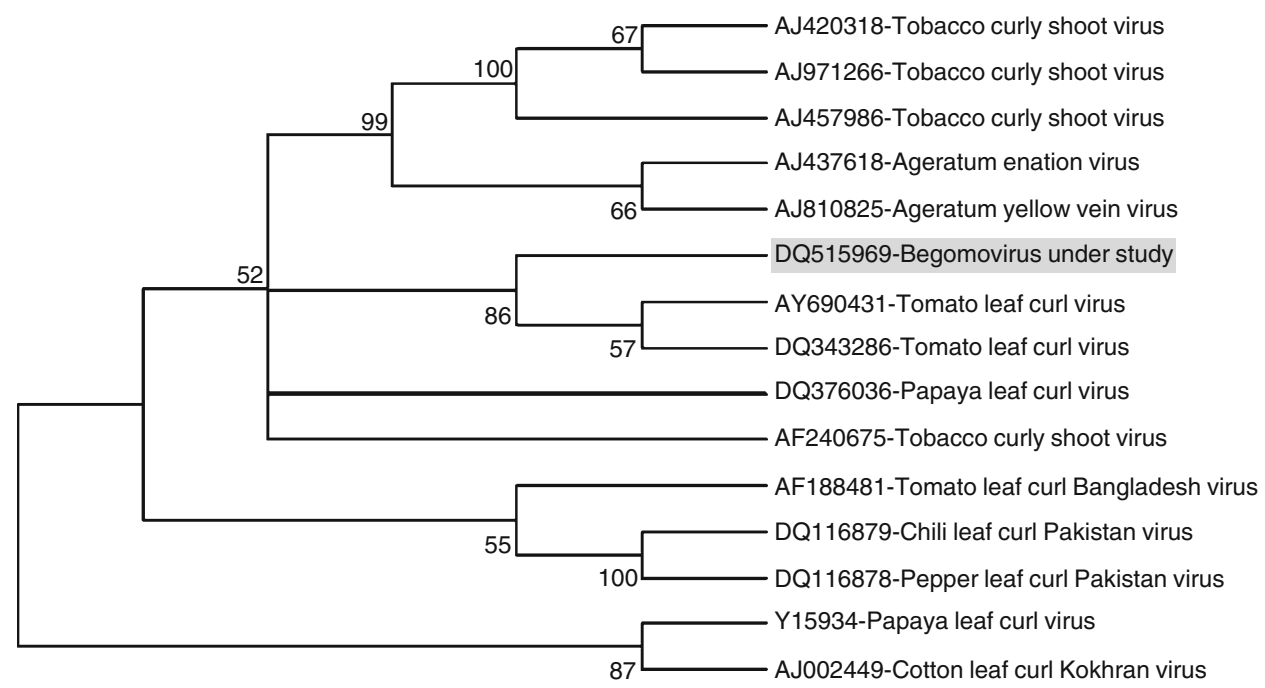

Fig. 2. Phylogenetic relationship of Dimorphotheca sinuata virus isolate with selected begomoviruses from India and abroad.

\section{References}

Lisa V (1995) Dimorphotheca sinuata. In 'Virus and Virus-like Diseases of Bulb and Flower Crops'. (Eds G Loebenstein, RH Lawson, AA Brunt) pp. 471-475. (John Wiley and Sons: New York)

Manoussopoulos IN, Chatzivassiliou EK, Smyrnioudis IN, Katis NI (1999) Two Diseases of Dimorphotheca caused by Lettuce mosaic potyvirus and Tomato spotted wilt tospovirus. Phytoparasitica 27, $1-6$.
Raj SK, Haq QMR, Srivastava KM, Singh BP (1994) Characterization of a virus causing severe mosaic disease in Dimorphotheca aurantiaca Hort. Indian Journal of Virology 10, 122-127.

Singh R (2005) Molecular characterization of a virus causing yellow mosaic disease in Cucurbita maxima and development of diagnostics for detection of the virus. PhD thesis, University of Lucknow, Lucknow, India.

Manuscript received 10 November 2006, accepted 28 January 2007 